\title{
The Romance of Learning from Disagreement. The Effect of Cohesiveness and Disagreement on Knowledge Sharing Behavior and Individual Performance Within Teams
}

\author{
Marianne van Woerkom · Karin Sanders
}

Published online: 17 September 2009

(c) The Author(s) 2009. This article is published with open access at Springerlink.com

\begin{abstract}
Purpose The purpose of this study was to explore the effects of disagreement and cohesiveness on knowledge sharing in teams, and on the performance of individual team members.

Design/methodology/approach Data were obtained from a survey among 1,354 employees working in 126 teams in 17 organizations.

Findings The results show that cohesiveness has a positive effect on the exchange of advice between team members and on openness for sharing opinions, whereas disagreement has a negative effect on openness for sharing opinions. Furthermore, the exchange of advice in a team has a positive effect on the performance of individual team members and acts as a mediator between cohesiveness and individual performance.

Implications Managers who want to stimulate knowledge sharing processes and performance within work teams may be advised to take measures to prevent disagreement between team members and to enhance team cohesiveness. Originality/value Although some gurus in organizational learning claim that disagreement has a positive effect on group processes such as knowledge sharing and team learning, this study does not support this claim.
\end{abstract}

Received and reviewed by former editor, George Neuman

M. van Woerkom $(\bowtie)$

Department of Human Resource Studies, Tilburg University, P.O. Box 90153, 5000 LE Tilburg, The Netherlands

e-mail: m.vanwoerkom@uvt.nl

K. Sanders

Twente University, Enschede, The Netherlands
Keywords Knowledge sharing behavior - Teams . Disagreement - Cohesiveness · Individual performance

\section{Introduction}

Although empirical evidence does not consistently support the claim that teams enhance performance, there is a 'romance of teams' (Allen and Hecht 2004) involving a strong faith in the effectiveness of team-based work which has caused teams to become a prominent feature of the organizational landscape. Instead of relying on functional structures, many organizations are adopting team-based structures in which teams are responsible for key organizational outputs (Beyerlein et al. 1995; McDermott 1999). In some cases, these are whole products or services, whereas in other cases, they are sub-products or elements of the organization's "value-chain" (Katzenbach and Smith 1993). Teams are supposed to stimulate the stronger need for flexibility, quality consciousness, and innovation (Anderson and Michael 1996; Lambert and Peppard 1993), because they give space for the creativity and problem solving competences of team members.

One of the expected yields of teamwork is the stimulation of team learning (Critchley and Casey 1989; Katzenbach and Smith 1993; Kofman and Senge 1993; Senge 1990; Tjosvold and Yu 2004). Teams bring together complementary skills and experience that exceed those of individual members in the team (Katzenbach and Smith 1993). Senge (1990) even claims that teams and not individuals are the fundamental learning unit in modern organizations: "unless the team can learn, the organization cannot learn" (p. 40). Whereas some authors define organizational learning or team learning as an outcome (Levitt and March 1988), others define learning as a process. 
Following Argyris and Schön (1996) and Edmondson (1999), we adhere to the latter approach and focus on the learning behaviors through which outcomes such as a better team performance can be achieved. More specifically, we focus on knowledge sharing behavior, as this is both a basic element of the team learning process (Wilson et al. 2007) and a condition for organizational learning (Hoopes and Postrel 1999; Nonaka and Takeuchi 1995). With an effective knowledge sharing process, organizations can develop their knowledge base and competitiveness (Andrews and Delahaye 2000; McEvily and Chakravarthy 2002).

Knowledge sharing within teams may occur via the advice-seeking behavior of team members (Podolny and Baron 1997). When team members ask for and give each other advice, they are likely to become more competent in task execution. In this study, we focus on the tendency of team members to ask for and give each other advice as an indicator for knowledge sharing within teams. Furthermore, we consider the openness of team members to share ideas and suggestions (Chow et al. 2000; Kasl et al. 1997) to be another important aspect of knowledge sharing.

Many gurus on organizational learning stress the importance of the role that disagreement can play in knowledge sharing or organizational learning (Argyris and Schön 1996; Senge 1990; Swieringa and Wierdsma 1990). In line with this, some studies confirm a positive effect from conflict on team learning (Ellis et al. 2003; Kasl et al. 1997; Van Offenbeek 2001). On the other hand, a meta-analysis shows negative relationships among conflict, team performance, and team member satisfaction (De Dreu and Weingart 2003). Moreover, disagreement within teams is likely to destroy the mutual trust and cooperation that is needed for effective knowledge sharing (Rastogi 2000). Therefore, in this study, we expect that, when team members disagree about ideas on what is important for their team, they are less likely to give and ask each other for advice and to listen to each others' suggestions (Moye and Langfred 2004). As sharing knowledge with other team members is a voluntary and conscious act conducted by an individual, we expect that the cohesiveness in a team also plays a role in knowledge sharing. Cohesiveness within a team refers to the affinity between group members and their identification as a group (Organ et al. 2006). Team members are more willing to show cooperative behavior to each other and tend to be more willing to aid and assist team members if the ties that bind them are stronger (Cartwright 1968; Davis 1969; Mullen and Copper 1994; Schachter et al. 1951).

In this article, we begin with an examination of the relationship between disagreement and cohesiveness. We then explore the relationship between knowledge sharing behavior within teams and individual performance of team members. The conceptual model upon which this study is

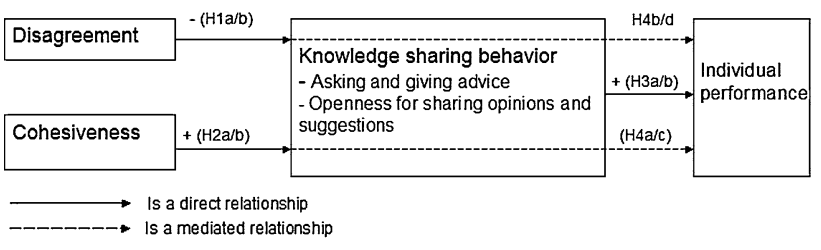

Fig. 1 Conceptual model

based is depicted in Fig. 1. Data for the study were gathered by means of a questionnaire, which was administered to 1,354 employees working in 126 teams within 17 Dutch organizations.

\section{Knowledge Sharing Within Teams}

In team contexts, people can learn, not only from their own direct experiences, but also from the experiences of other team members (Ickes and Gonzalez 1994; Jarvis 1995). Because team members can interact with one another, knowledge gathered by one team member can be transferred to his/her teammates through feedback, explanation, help, or advice (Ellis et al. 2003; Tjepkema 2003). Exchange of knowledge between team members brings knowledge sources together and manipulates it into new knowledge structures or routines (Clark et al. 2002). Van Offenbeek (2001) speaks in this context about the information distribution process, whereby team members distribute information from different sources to the other members of the team. Kasl et al. (1997) speak of individuals sharing information and perspectives in the interest of team efficiency and effectiveness. According to Dillen and Romme (1997) and Senge (1990), dialogue stimulates team members to think together, so that individual opinions play a role but are not decisive. Edmondson et al. (2001) found that cardiac surgery teams whose members felt comfortable making suggestions to each other were more successful in learning new procedures. When people felt uneasy acting this way, the learning process was stifled.

As learning from secondary experience seems to be the key element in team learning, this study focuses on team members' ability to collectively share that experience with their team mates (Dillen and Romme 1997; Ellis et al. 2003) by asking and giving advice to each other and by being open to hearing ideas, opinions, or suggestions from each other (Kasl et al. 1997).

\section{The Relationship Between Disagreement} and Knowledge Sharing Within Teams

Despite the voluminous work on conflict, a clear generally accepted definition and typology of the construct is still lacking (Barki and Hartwick 2004; Wall and Callister 1995). Conflict can be seen as one of the challenges of working 
effectively in teams (De Dreu and Weingart 2003). Three properties can be identified as underlying many descriptions of what conflict is: disagreement, negative emotion, and interference (Barki and Hartwick 2004). More recently, researchers have identified task conflict, or cognitive conflict (Amason 1996), as one type of conflict. Although definitions of this construct have essentially focused on perceived disagreements, others include negative emotions (Jehn and Mannix 2001). For reasons of conceptual clearness, this study focuses on disagreement about ideas and goals.

The literature on the effects of disagreement or task conflict on team processes is inconclusive. On the one hand, some studies show that facile and uncritical agreement within the team can have a negative impact on problem solving (Aldag and Fuller 1993; Janis 1985), whereas conflict forces individuals to think more deeply and more creatively about the problem they have to solve. Van Offenbeek (2001) finds that the more divergent the ideas team members have about the task initially are, the more team members will experience having learned something at the end. Sauquet (2002) concludes that the inability to face conflict in a more global way makes creation of collective knowledge impossible. This is in line with De Dreu (1997), Turner and Pratkanis (1997), and Janis (1972), who argue that conflict suppression reduces individual creativity and decision-making quality in teams.

On the other hand, Stock (2004) concludes from a literature review based on 72 empirical studies investigating the antecedents of team performance that both positive and negative effects have been found for task-related conflicts. De Dreu and Weingart (2003) found a strong negative relationship between task conflict and team performance in their meta-analysis of 30 studies.

Although there are no studies available on the relation between disagreement and knowledge sharing activities, such as advice seeking behavior and openness for sharing opinions and suggestions, it is more likely that when team members disagree with each other they will be less inclined to ask and give advice to each other and to be open to hearing the ideas, opinions, and suggestions of team members. Therefore, it is hypothesized that disagreement is negatively related to asking and giving advice to each other (Hypothesis 1a) and that disagreement is negatively related to openness for sharing opinions and suggestions (Hypothesis 1b).

\section{The Relationship Between Cohesiveness and Knowledge Sharing Within Teams}

When team members undertake activities together, such as having lunch together, visiting each other at home, or having a drink after work, they get to know each other better and relations become stronger, making the team more cohesive
(Sanders and Van Emmerik 2004). Cohesiveness increases the energy team members can devote to task-related activities because team maintenance needs are reduced. Highly cohesive teams experience less inter-member friction, higher member trust, and greater interpersonal coordination (Dobbins and Zaccaro 1986). Furthermore, research shows positive relationships between cohesiveness and employee satisfaction (Dobbins and Zaccaro 1986), as well as cohesiveness and cooperative behavior (Kidwell et al. 1997; Sanders and Van Emmerik 2004), and also shows negative relationships between cohesiveness and (short-term) absenteeism (Sanders 2004; Sanders and Hoekstra 1998). Shaw (1981) argues that members of highly cohesive teams are likely to be more motivated to achieve established team goals. Based on a survey of managers, Berman et al. (2002) show that workplace friendship increases openness, communication, and task accomplishment.

Given the above-mentioned research, it is likely that team cohesiveness plays a role in knowledge sharing within teams, as well. Research from workplace-learning behavior shows that individuals tend to attribute more of their learning to informal support of co-workers than to formal training provided by the organization (Maurer et al. 2003; Tannenbaum 1997). In this way, knowledge sharing within a team can be seen as cooperative behavior of team members, which has shown to be affected by the cohesiveness of a team. As sharing knowledge with other team members is a voluntary and conscious act on the part of an individual (Dixon 2002; Nonaka 1994), involving commitment from both transmitter and receiver (Michailova and Hutchings 2006), we hypothesize that cohesiveness in a team is positively related to asking and giving advice (Hypothesis 2a) and that cohesiveness in a team is positively related to openness for sharing opinions and suggestions (Hypothesis 2b).

\section{Knowledge Sharing and Individual Performance}

For the past decade, practitioners have pronounced the importance of knowledge sharing for organizational effectiveness. Yet, research has only begun to examine the empirical relationship between knowledge sharing and both team and individual performance (Druskat and Kayes 2000). Although empirical evidence does not consistently support the claim that teams enhance performance (Allen and Hecht 2004), some authors have found positive relationships. Bunderson and Sutcliffe's (2003) study of management teams showed that an appropriate emphasis on learning has positive consequences for team effectiveness. Van Offenbeek (2001) found that the activities 'information storage and retrieval' and 'acquiring information' influenced the performance of student teams positively. 
Edmondson et al. (2001) also found evidence for a positive relationship between a team's learning focus and observer ratings of overall team effectiveness in a sample of manufacturing teams. In this study, we will focus on individual performance instead of team performance. As it is likely that the performance of individual team members will also benefit from the advice and feedback from their team members (Kluger and DeNisi 1996; Moye and Langfred 2004; Pearsall and Ellis 2006; Tindale et al. 1991), we hypothesize that asking and giving advice is positively related to individual performance (Hypothesis 3a) and that openness for sharing opinions and suggestions is positively related to individual performance (Hypothesis $3 b$ ).

Summarizing the above hypotheses, we expect that knowledge sharing is an intermediate variable in the relationship between cohesiveness and disagreement, on the one hand, and individual performance, on the other hand. Consequently, we hypothesize that asking and giving advice mediates the relationship between cohesiveness (Hypothesis 4a) and disagreement (Hypothesis 4b), on the one hand, and individual performance, on the other hand. Furthermore, we hypothesize that openness for sharing opinions and suggestions mediates the relationship between cohesiveness (Hypothesis 4c) and disagreement (Hypothesis 4d), on the one hand, and individual performance, on the other hand.

\section{Method}

\section{Respondents}

We employed a cross-sectional design in which we sampled teams from a wide range of organizations both in the public sector (three faculties of a university, a ministry, departments of the royal air force, a nursing home, a swimming pool) and in the private sector (a consultancy firm, some small manufacturing organizations). Although our sample consists of a diversity of teams, all respondents participated in ongoing teams, with long task duration, and involving between 5 and 15 team members. Although the task performed by the individual teams differed, in all cases, the team members needed each other to complete the team's product or service.

Questionnaires were distributed to a total of 3,312 respondents. The overall response rate was $45 \%$. The response rate differed between organizations (between 21 and 90\%) and between teams (between 5 and 100\%). Due to the fact that some measures were based on team measures, only data from employees for which there were at least five respondents from their team were retained, as past research has indicated that biases in using aggregate scores begin to diminish with groups of five or more employees (Bliese 2000). As teams with less than five respondents were excluded from our sample, our final sample consisted of 1,354 respondents from 126 teams in 17 Dutch organizations, with an average group size of 10.7 responding workers per team.

$60 \%$ of the respondents were male; the mean age was 40.8 years $(S D=11.76) .77 \%$ of the respondents had a higher education background. Most employees (76\%) had a permanent contract, $8 \%$ had a temporary job with the perspective of a permanent job in the near future, and $8 \%$ had a temporary job. The respondents had, on average, 12.2 years work experience within the current organization $(S D=9.7)$ and 5.5 years work experience in the current position $(S D=5.12)$. The mean total work experience was 16.9 years $(S D=10.9)$. The respondents worked, on average, $27.9 \mathrm{~h}$ a week $(S D=14.4)$.

\section{Procedure}

Before the questionnaires were distributed, stage meetings were held with the board of directors and the managers of all the organizations (see Lambooij et al. 2002). The relevant unions and works councils were also informed of the goals, design, and possible consequences of the research. Thereafter, all employees were informed about the research and the way the data would be collected. In all of the different organizations, the data were collected by master students who used the data from the specific organization for writing a master thesis. Within all organizations, these students personally handed over the questionnaires and reply envelopes to the employees. The respondents were asked to send the completed questionnaire by means of the reply envelope to the university. Employees were told that data would be collected about their experiences working within a team. Employees answered the questionnaire voluntarily; there were no consequences for answering the questionnaire, neither positive nor negative. These activities contributed to the relatively high survey response rate of $45 \%$, with no discernible difference between respondents and nonrespondents (Buffinga 2004; Jonker 2003). The sample's demographic (gender, age, education, type of labor contract, and number of working hours) show similarities with the Dutch working population (CBS 2004, 2005), although not in all respects. ${ }^{1}$ The dataset over-represents employees with

\footnotetext{
${ }^{1}$ Details of the sample compared to national statistics in brackets are as follows: $60 \%$ of the respondents $(51 \%)$ were male, with the mean age of 40.8 (42.6) years of age $(S D=11.76)$. Seventy-seven percent of the respondents $(27 \%)$ had a higher vocational education $(S D=1.69)$. Eighty-four percent $(82 \%)$ were employed on a permanent contract, $8 \%$ were presently in a temporary job but were anticipating a permanent job in the near future, and a further $8 \%$ were being employed as temporary workers. The respondents had worked an average of $27.9 \mathrm{~h}(32.2)$ a week $(S D=14.4)$, had, on average, 12.2 (15.4) years work experience within this organization $(S D=9.7)$ and 5.5 (7.2) years work experience in their current position $(S D=5.12)$.
} 
a higher vocational education background working in public sector organizations. ${ }^{2}$

\section{Measures}

All items of the scales that were used in this study were measured with a 7-point Likert-type scale ( $1=$ strongly disagree, $7=$ strongly agree). An exception to this was the cohesiveness scale that consists of seven points with different anchors ( $1=$ nobody, $7=$ everyone). The items that comprise the different scales are included in Appendix.

Disagreement was measured with a 3 -item scale that is part of the outcome interdependence scale of Van der Vegt et al. (1998). An example is "In my team we often have disagreements concerning ideas." The reliability of this 3 -item scale was good $(\alpha=.91)$.

Cohesiveness within a team was measured with a scale adapted from Dobbins and Zaccaro (1986), which consists of eight items concerning team members' willingness to share activities and to have personal talks. Examples of the items were "With how many people in your team do you occasionally talk about personal things?" and "With how many people in your team did you engage in one of the following activities: went for dinner, went to the movies, went visiting?" Answers ranged from $1=$ nobody, to $7=$ everybody. The scale was reliable $(\alpha=.90)$.

For knowledge sharing, two measures were used. First, we measured the extent to which team members ask and give advice to their team members with a self-developed 5-item scale. Examples of these questions are "Colleagues ask me for my advice regularly," and "I regularly ask my supervisor for advice." Although the reliability of this scale was sufficient but not high $(\alpha=.71)$, based on theoretical grounds, we decided to keep all five items within in the scale.

Secondly, to measure the openness for sharing opinions and suggestions, three items of the scale developed by Costa (2000) were used. Examples of items are "In team meetings, people are reluctant to give their opinion" and "Most people in my team are not interested in ideas or suggestions made by others." The reliability of the scale was good $(\alpha=.84)$. For this study, items were recoded so that low scores indicate little openness and high scores indicate high openness.

To measure individual performance, we used four items from the subjective performance scale part of organizational citizenship behavior (MacKenzie et al. 1991). Examples of items are "I consider myself one of the best

\footnotetext{
2 The survey did not ask respondents for their occupation or job description. Rather, to compare different jobs, employees were asked about the level of responsibility and autonomy that their work entailed.
}

employees of this organization," and "If I compare myself to my near colleagues, I am better in my job" $(\alpha=.77)$.

Control Variables

As various studies have indicated that the positive effects of teams depend on work, worker, and team characteristics (Barrick et al. 1998; Campion et al. 1996; Stewart and Barrick 2000), we included job, employee, and team characteristics as control variables.

\section{Job Characteristics}

Respondents were asked about their labor contract $(0=$ permanent labor contract, $1=$ temporary labor contract) and number of working hours a week. The autonomy and responsibility of the job were asked with a single item "How much autonomy/responsibility do you have in your job." Answers could be given on a 7-point scale $(1=$ low, 7 = high).

\section{Employee Characteristics}

Respondents were asked to answer questions concerning gender $(0=$ male, $1=$ female), age ("year of birth," which was recoded), level of education on a 7-point scale of educational qualifications $(1=$ secondary school, 7 = post graduate university level), and number of years within organization.

\section{Team Characteristics}

We have added team size to our analyses, because previous studies (Mohammed and Angell 2004; Steiner 1972; Wilke and Meertens 1994) have shown this variable to be relevant to team effectiveness. For this control variable, we used the number of team members and not the number of respondents from the different teams.

\section{Analysis}

The measures of disagreement and cohesiveness that are used in this study refer to characteristics of teams instead of characteristics of individual employees. For instance, a team is more or less cohesive, not an employee. Asking and giving advice and openness, on the other hand, are interpreted in this study as perceptions of the employees and taken into account on the individual level. Because of this, aggregation characteristics (values of ICC1 and ICC2; Bliese 2000) were calculated for disagreement and cohesiveness. The values of ICC1 are similar to what is found in the research literature (e.g., values in the range of .05 to .15; disagreement: .15; cohesiveness: .12). Given the number of 
groups in the study, we can assume there is enough agreement within groups to make our study feasible. Values of ICC2 above .50 are acceptable (Klein and Kozlowski 2000), whereas values above .70 are considered good. The ICC2 for disagreement is .58, and for cohesiveness, .64. This means that the different scales intended for this study are acceptable on a team level.

The dataset consisted of employees nested in teams, which were in turn nested in organizations. Because the variance of the different dependent variables (asking and giving advice, openness, and individual performance) is hardly related to the organization level (ranging from .01 to $.19 \%$ ), this level is not taken into account. This means that the data can be conceptualized at two levels (employee and teams). Level 1 captures the information of the employees in each team (the two aspects of knowledge sharing for the first analyses and the perceived individual performance for the second analyses), and level 2 captures the variability between teams (disagreement and cohesiveness). In such situations, it is appropriate to use a hierarchical 2-level modeling approach that simultaneously models effects at the within- and between subunit-level (Raudenbush and Bryk 2002). We used the statistical package MLWIN V1.02 to analyze our two-level data.

The data were analyzed using hierarchical regression analyses. First, the mediating variables (asking and giving advice and openness) were regressed on the independent variables (disagreement and cohesiveness). The results of these analyses are presented in Table 2. Second, the dependent variable individual performance was regressed on the independent and mediating variables (Table 3 ).

\section{Results}

Table 1 provides the means, standard deviations, and correlations for all variables included in this study. As we can see, there was a significant positive relationship between cohesiveness and openness $(r=.32, p<.01)$. There were strong significant negative relationships between disagreement and asking and giving advice $(r=-.45$, $p<.01)$ and between disagreement and openness $(r=$ $-.37, p<.01)$. Further, asking and giving advice had a positive relationship with perceived individual performance $(r=.11, p<.05)$.

From the correlations with the control variables, we can see that a significant positive correlation exists for both job autonomy and job responsibility with respect to individual performance, asking and giving advice, and openness. The number of years in the organization relates significantly positive with openness, and significantly negative with disagreement. Females have significantly higher values for individual performance and for openness. Age relates significantly positive with individual performance and disagreement. Educational level relates significantly negative with individual performance and also significantly negative with disagreement. Team size relates significantly positive with perceived individual performance, but significantly

Table 1 Descriptives and correlations between variables $(n=1,354)$

\begin{tabular}{|c|c|c|c|c|c|c|c|c|c|c|c|c|c|c|c|}
\hline Scales & Mean & SD & 1 & 2 & 3 & 4 & 5 & 6 & 7 & 8 & 9 & 10 & 11 & 12 & 13 \\
\hline $\begin{array}{l}1 \text { Individual } \\
\text { performance }\end{array}$ & 4.72 & 2.49 & & & & & & & & & & & & & \\
\hline $\begin{array}{l}\text { 2. Asking and giving } \\
\text { advice }\end{array}$ & 4.96 & 2.36 & $.11^{*}$ & & & & & & & & & & & & \\
\hline 3. Openness & 4.00 & 1.13 & .06 & $.14^{*}$ & & & & & & & & & & & \\
\hline 4. Cohesiveness & 3.66 & 1.12 & $.12^{*}$ & .08 & $.32 * *$ & & & & & & & & & & \\
\hline 5. Disagreement & 2.18 & 2.16 & .06 & $-.45^{* *}$ & $-.37 * *$ & -.09 & & & & & & & & & \\
\hline 6. Type of contract & .24 & .49 & .02 & .02 & -.01 & $.10^{*}$ & -.06 & & & & & & & & \\
\hline 7. No. of hours/week & 27.9 & 14.3 & .04 & -.01 & -.10 & -.07 & .05 & $.07 *$ & & & & & & & \\
\hline 8. Job autonomy & 5.73 & 1.19 & $.17 * *$ & $.09 *$ & $.24 * *$ & .01 & .05 & $-.07 *$ & .06 & & & & & & \\
\hline 9. Job responsibility & 6.04 & 1.02 & $.21 * *$ & $.08^{*}$ & $.11 *$ & .08 & -.01 & .01 & .04 & $.58 * *$ & & & & & \\
\hline $\begin{array}{l}\text { 10. No. of years in } \\
\text { organization }\end{array}$ & 12.2 & 9.70 & .05 & .09 & $.24 * *$ & .01 & $-.18^{*}$ & $.28 * *$ & $-.15^{*}$ & $-.18 * *$ & -.07 & & & & \\
\hline $\begin{array}{l}\text { 11. Gender } \\
(0=\text { male })\end{array}$ & .40 & .49 & -.02 & -.02 & $.12 *$ & -.04 & .01 & $-.14 *$ & $-.14 *$ & $-.14 *$ & -.02 & $.30 * *$ & & & \\
\hline 12. Age & 40.8 & 11.7 & $.10 * *$ & -.02 & .06 & -.04 & $.10^{*}$ & -.01 & $-.14 *$ & $-.14^{*}$ & -.07 & $.20 * *$ & .04 & & \\
\hline 13. Education & 5.76 & 1.69 & -.17 & .05 & .03 & -.01 & $-.18^{*}$ & $.10^{*}$ & $.23 * *$ & .06 & .03 & $.22 * *$ & .03 & $.07 *$ & \\
\hline 14. Team size & 8.91 & 2.39 & $.24 * *$ & $-.11 *$ & $-.13^{*}$ & $-.14^{*}$ & $-.18^{*}$ & -.04 & $.10^{*}$ & $-.18^{*}$ & $-.17 *$ & -.07 & -.06 & -.05 & .04 \\
\hline
\end{tabular}

$* p<.05, * * p<.01$ 
Table 2 Results of regression analyses with asking and giving advice and openness as dependent variables (multi level analyses; $n=1,354)$

\begin{tabular}{|c|c|c|c|c|c|c|}
\hline & \multicolumn{3}{|c|}{ Asking and giving advice } & \multicolumn{3}{|l|}{ Openness } \\
\hline & Empty model & Model 1 & Model 2 & Empty model & Model 1 & Model 2 \\
\hline \multicolumn{7}{|l|}{ Individual level } \\
\hline Type of labor contract $(0=$ permanent $)$ & & -.08 & -.04 & & -.01 & .01 \\
\hline No. of hours a week & & -.09 & -.07 & & .09 & .10 \\
\hline Job autonomy & & .09 & .06 & & $.27 * *$ & $.19 *$ \\
\hline Job responsibility & & $.20^{*}$ & $.21^{*}$ & & .03 & .06 \\
\hline No. of years & & -.06 & -.06 & & $-.22 * *$ & $-.20 *$ \\
\hline Age & & .15 & .12 & & .11 & .05 \\
\hline Gender $(0=$ male $)$ & & -.04 & -.06 & & .11 & .05 \\
\hline Education & & $-.19 * *$ & $-.20 * *$ & & $-.18 * *$ & $-.15^{*}$ \\
\hline \multicolumn{7}{|l|}{ Team level } \\
\hline Cohesiveness & & & $.09 *$ & & & $.48 * *$ \\
\hline Disagreement & & & -.17 & & & $-.28 * *$ \\
\hline Team size & & .01 & .02 & & .01 & .01 \\
\hline Constant & $3.97 * *$ & $3.54 * *$ & $4.11 * *$ & $4.70 * *$ & $4.66 * *$ & $4.54 * *$ \\
\hline Variance individual level & 10.72 & 9.85 & 7.91 & 98.43 & 92.23 & 85.73 \\
\hline Variance team level & 2.26 & 2.2 & 1.94 & 8.37 & 8.14 & 6.45 \\
\hline Model fit & 486.34 & $442.13 * *$ & $439.1 * *$ & 463.87 & $459.21 *$ & $407.8 *$ \\
\hline
\end{tabular}

$* p<.05, * * p<.01$

negative with asking and giving advice, openness, cohesiveness, and disagreement.

To test the first and second hypotheses, we turn to the results of the hierarchical regression analyses with the individual-level-dependent variables 'asking and giving advice' and 'openness' reported in Table 2. As we can see in Table 2, Hypothesis 1a, which predicts a negative relationship between disagreement and asking and giving advice, could not be supported ( $B=-.17$, n.s.). However, a negative relationship was indeed found between disagreement and openness $(B=-.28, p<.01)$, so that Hypothesis $1 \mathrm{~b}$ could be supported. Furthermore, as we can see in Table 2, Hypotheses $2 \mathrm{a}$ and $2 \mathrm{~b}$, which predict a positive relationship between cohesiveness, on the one hand, and asking and giving advice and openness, on the other hand, could both be supported $(B=.09, p<.05$; and $B=.48 ; p<.01)$.

The results of the regression analyses with individual performance as dependent variable are reported in Table 3. As we can see in Table 3 (model 1), Hypothesis 3 a concerning the relationship between asking and giving advice and individual performance is supported $(B=.42$, $p<.01)$. There is, however, no support for Hypothesis $3 \mathrm{~b}$ concerning the relationship between openness and individual performance ( $B=.11$, n.s.).

Hypothesis $4 \mathrm{a}$ concerned the mediating role of asking and giving advice in the relationship between cohesiveness and perceived individual performance. This hypothesis can be confirmed as cohesiveness showed to have a significant effect on asking and giving advice $(B=.09, p<.05)$, asking and giving advice has a significant effect on individual performance $(B=.39, p<.01)$, and cohesiveness has a significant relationship with individual performance that disappears when asking and giving advice is added to the model ( $B=.05$, n.s.). As there is no significant effect from disagreement on asking and giving advice $(B=-.17$, n.s.), this latter variable does not have a mediating effect in the relationship between disagreement and individual performance, so that Hypothesis $4 \mathrm{~b}$ cannot be confirmed. Furthermore, Hypothesis $4 \mathrm{c}$ concerning the mediating role of openness in the relationship between cohesiveness and perceived individual performance and Hypothesis $4 \mathrm{~d}$ concerning the mediating role of openness in the relationship between disagreement and individual performance cannot be confirmed as there is no effect from openness on individual performance. Figures 2 and 3 show our empirical findings regarding the conceptual model.

\section{Conclusions}

In this study, we investigated the relationships between disagreement and cohesiveness in teams, on the one hand, and knowledge sharing in teams and individual performance, on the other. As teams have become a prominent feature of the organizational landscape, and as organizations have to 'learn' in order to successfully compete, it is important to know what conditions stimulate knowledgesharing behavior in teams. 
Table 3 Results of regression analyses with individual performance as dependent variable $(n=1,354)$

\begin{tabular}{|c|c|c|c|c|}
\hline & Empty model & Model 1 & Model 2 & Model 3 \\
\hline \multicolumn{5}{|l|}{ Individual level } \\
\hline Type of labor contract $(0=$ permanent $)$ & & .02 & .07 & .07 \\
\hline No. of hours a week & & -.12 & -.11 & -.10 \\
\hline Job autonomy & & .05 & .05 & .02 \\
\hline Job responsibility & & -.04 & -.03 & .03 \\
\hline No. of years & & $.25 * *$ & $.29 * *$ & $.21 * *$ \\
\hline Age & & $.09 *$ & $.10 *$ & .08 \\
\hline Gender $(0=$ male $)$ & & .08 & .10 & .07 \\
\hline Education & & $-.11 *$ & $-.12 *$ & $-.11 *$ \\
\hline Asking and giving advice & & $.42 * *$ & & $.39 * *$ \\
\hline Openness & & .11 & & .12 \\
\hline \multicolumn{5}{|l|}{ Team level } \\
\hline Cohesiveness & & & $.17 * *$ & .05 \\
\hline Disagreement & & & .17 & .14 \\
\hline Team size & & & -.02 & -.02 \\
\hline Constant & $4.81 * *$ & $4.80 * *$ & $4.89 * *$ & $4.62 * *$ \\
\hline Variance individual level & 48.33 & 47.31 & 43.55 & 43.42 \\
\hline Variance team level & 10.82 & 10.80 & 10.14 & 10.09 \\
\hline Model fit & 682.89 & $675.80^{* *}$ & $617.44 * *$ & $605.12 * *$ \\
\hline
\end{tabular}

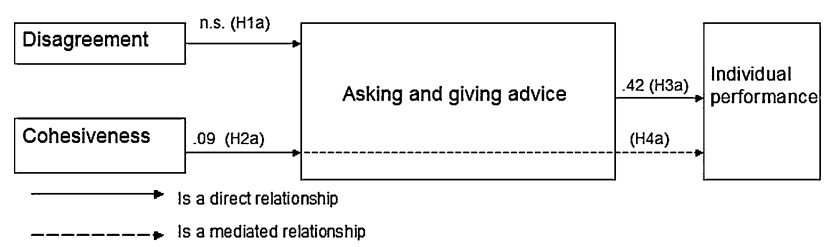

Fig. 2 Empirical results for asking and giving advice

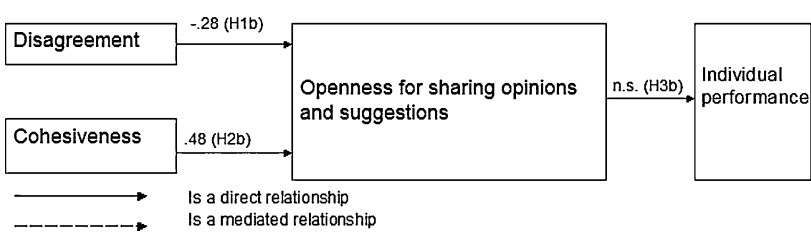

Fig. 3 Empirical results for openness for sharing opinions and suggestions

Although many authors report a positive effect from disagreement on group processes such as knowledge sharing and team learning (Ellis et al. 2003; Kasl et al. 1997; Van Offenbeek 2001), this study does not confirm these results. The results show that there is a significant negative main effect from disagreement on openness for sharing ideas and suggestions. Perhaps the expected positive effect of disagreement on knowledge sharing is part of the 'romance of teams' (Allen and Hecht 2004).

Our results are, however, in line with a meta-analysis conducted by De Dreu and Weingart (2003), in which strong and negative (instead of the predicted positive) correlations between task conflict and team performance and a less negative effect of task conflict on team performance when task conflict and relation conflict were weakly correlated were found. De Dreu and Weingart (2003) suggest that the fact that results showed no differential relationship between type of conflict and team performance might be caused by a measurement problem, since most research included in their analysis relied on the scale developed by Jehn $(1994,1995)$. However, as we used a self-developed scale for disagreement, and, as we found negative effects from this variable on knowledge sharing within teams, this explanation seems less plausible. More plausible is that high levels of disagreement can stifle knowledge sharing by creating barriers in communication (Tjepkema 2003), harming interpersonal understanding (Druskat and Kayes 2000), or producing affective conflicts (Devine 1999). Another explanation might be that the relation between disagreement and knowledge sharing is an inverted U-shaped relationship (Stock 2004). Studies (Jehn 1995; Stock 2004) based on nonlinear models have suggested that both too few and too intensive task-related conflicts reduce team performance. The same may apply to knowledge sharing: only when there are neither too many nor too few diverging views in a team will each team member be open to new ideas and enter into a cognitive mode that allows for the questioning of assumptions and the generation of new insights (Driver 2003).

Our study did confirm the importance of cohesiveness for knowledge sharing and the importance of knowledge sharing as an intermediate variable between cohesiveness, 
on the one hand, and team performance, on the other hand. Our study shows that asking and giving advice within teams can be seen as a pure mediating variable in the relationship between cohesiveness and the individual performance of team members. Team cohesiveness in and of itself is not enough to enhance individual performance.

The results of this study are in line with the results reported by Edmondson (1999), who claims a positive effect from team psychological safety on team-learning behavior. However, Edmondson warns that team psychological safety is not the same as group cohesiveness, as earlier research (Janis 1982) has shown that cohesiveness can reduce willingness to disagree and challenge others' views, as in the phenomenon of groupthink, which implies a lack of interpersonal risk-taking. Our study shows nevertheless that the positive sides of team cohesiveness are probably stronger than its negative sides, as we have found no significant relationship between cohesiveness and disagreement and as we have found a positive effect from cohesiveness on knowledge sharing within teams. This means that team members in cohesive teams disagree just as much with each other as team members in non-cohesive teams, but that they do share more knowledge with each other, probably because they feel more motivated to achieve established team goals.

This study has limitations and strengths. The first limitation is that we used a cross-sectional design, which makes it impossible to draw conclusions about the causality of relationships. Future research into knowledge sharing in teams using a longitudinal approach should shed more light on this. A second limitation is that we measured the perception of individual performance instead of some objective measure for team performance. In a following study, more objective measures of both individual and team performance should be included. Another possible avenue for future research is to not only look for existence of disagreement, but also for the ability of teams to manage conflicts (De Reuver 2006; Shaw and Barrett-Power 1998). Strength of this study is that it focuses on knowledgesharing behavior as a mediating variable between cohesiveness and disagreement, on the one hand, and individual performance of team members, on the other hand. While the effects of conflict on group performance have been studied and discussed extensively (De Dreu and Weingart 2003), the relationship between conflict and knowledge sharing has not been explored fully (Moye and Langfred 2004). This study is certainly not the final word on the relationship between disagreement and knowledge sharing. More studies in the proposed directions are needed in order to refine and possibly replicate our findings. Our study does indicate, however, that the relationship between disagreement and collective learning that is stressed by some gurus in organizational learning is a complex relationship.
Sorting out how relationships between team members influence the learning behavior and the performance of individuals and teams may be a key element for understanding collective learning processes in organizations.

Open Access This article is distributed under the terms of the Creative Commons Attribution Noncommercial License which permits any noncommercial use, distribution, and reproduction in any medium, provided the original author(s) and source are credited.

\section{Appendix}

\section{See (Table 4).}

Table 4 Variable scales

Disagreement $(\alpha=.91)$

1. In my team we often have disagreements concerning ideas

2. We agree on what is important for our team $(R)$

3. The goals of different team members are not in line with each other Cohesiveness $(\alpha=.90)$

1 . With how many people in your team do you cooperate regularly?

2. With how many people in your team do you occasionally talk about personal things?

3. With how many people do you engage in activities in- and outside of work?

4. With how many people do you have a good personal relationship?

5. With how many people did you engage in one of the following activities: to go to dinner, to go to the movies, visiting?

6. With how many people do you talk about work or other business, considering the last three months?

7. What do you think about the mutual cooperation with your team members during the last three months?

8. How do you feel about your personal relationship with your coworkers in your team during the last three months? ${ }^{\mathrm{a}}$

Asking and giving advice $(\alpha=.71)$

1. Colleagues ask me for my advice regularly

2. Colleagues and supervisors listen when I give advice on job related matters

3. My supervisor asks me for my advice

4. I regularly ask my supervisor for advice

5. I regularly ask my colleagues for advice

Openness $(\alpha=.84)$; all items are reversed

1. In team meetings, people are reluctant to give their opinion

2. In my team, people do not always open up

3. Most people in my team are not interested in ideas or suggestions made by others

Individual performance $(\alpha=.77)$

1. I consider myself one of the best employees of this organization

2. I consider myself one of the most valuable employees of this organization

3. I am satisfied with my job performance

4. If I compare myself to my closest colleagues, I am better in my job

a The answers for the last two items are $1=$ very bad; $7=$ very good 


\section{References}

Aldag, R. J., \& Fuller, S. R. (1993). Beyond fiasco: A reappraisal of the groupthink phenomenon and a new model of group decision processes. Psychological Bulletin, 113, 533-552.

Allen, N., \& Hecht, T. D. (2004). The 'romance of teams': Toward an understanding of its psychological underpinnings and implications. Journal of Occupational and Organizational Psychology, 77, 439-461.

Amason, A. C. (1996). Distinguishing the effects of functional and dysfunctional conflict on strategic decision making: Resolving a paradox for management teams. The Academy of Management Journal, 39, 123-148.

Anderson, N., \& Michael, A. W. (1996). The team climate inventory: Development of the TCI and its applications in teambuilding for innovativeness. European Journal of Work and Organizational Psychology, 5, 53-66.

Andrews, K. M., \& Delahaye, B. L. (2000). Influences on knowledge processes in organizational learning: The psychosocial filter. The Journal of Management Studies, 37, 797-810.

Argyris, C., \& Schön, D. A. (1996). Organizational learning II: Theory, method and practice. Reading, MA: Addison-Wesley Publishing Company.

Barki, H., \& Hartwick, J. (2004). Conceptualizing the construct of interpersonal conflict. The International Journal of Conflict Management, 15, 216-244.

Barrick, M. R., Stewart, G. L., Neubert, M. J., \& Mount, M. K. (1998). Relating member ability and personality to work-team processes and team effectiveness. Journal of Applied Psychology, 83, 377-391.

Berman, E. M., West, J. P., \& Richter, J. M. N. (2002). Workplace relations: Friendship patterns and consequences (according to managers). Public Administration Review, 62(2), 217-230.

Beyerlein, M. M. E., Johnson, D. A. E., \& Beyerlein, S. T. E. (1995). Advances in interdisciplinary studies of work teams: Knowledge work in teams (XIX ed., Vol. 2). Stanford, CT: JAI Press, Inc.

Bliese, P. D. (Ed.). (2000). Within-group agreement, non-independence, and reliability: Implications for data aggregation and analyses. San Francisco: Jossey-Bass.

Buffinga, E. (2004). Commitment and solidarity behaviours: Common future? Unpublished Master's Thesis, Tilburg University, The Netherlands.

Bunderson, J. S., \& Sutcliffe, K. M. (2003). Management team learning orientation and business unit performance. Journal of Applied Psychology, 88, 552-560.

Campion, M. A., Papper, E. M., \& Medsker, G. J. (1996). Relations between work team characteristics and effectiveness: A replication and extension. Personnel Psychology, 49, 429-452.

Cartwright, D. (1968). The nature of group cohesiveness. In D. C. A. Zander (Ed.), Group dynamics: Research and theory (Vol. 91109). New York: Harper and Row.

CBS. (2004). Figures for the central database of Statistics Netherlands. From http://statline.cbs.nl/statweb.

CBS. (2005). Figures for the central database of Statistics Netherlands. From http://statline.cbs.nl/statweb.

Chow, C. W., Deng, F. J., \& Ho, J. L. (2000). The openness of knowledge sharing within organizations: A comparative study in the United States and the people's republic of china. Journal of Management Accounting Research, 12, 65-95.

Clark, M. A., Amundsen, S. D., \& Cardy, R. L. (2002). Cross-functional team decision-making and learning outcomes: A qualitative illustration. Journal of Business and Management, 8(3), 217-236.

Costa, A. C. (2000). A matter of trust: Effects on the performance and effectiveness of teams in organizations. Unpublished Doctoral Dissertation, Tilburg University, The Netherlands.
Critchley, B., \& Casey, D. (1989). Organisations get stuck too. Leadership \& Organization Development Journal, 10(4), 3-12.

Davis, J. (1969). Group performance. Reading, MA: AddisonWesley.

De Dreu, C. K. W. (1997). Productive conflict: The importance of conflict management and conflict issue. In C. K. W. De Dreu \& E. Van de Vliert (Eds.), Using conflict in organizations. Thousand Oaks, CA: Sage.

De Dreu, C. K. W., \& Weingart, L. R. (2003). Task versus relationship conflict, team performance, and team member satisfaction: A meta-analysis. Journal of Applied Psychology, $88,741-749$.

De Reuver, R. (2006). The influence of organizational power on conflict dynamics. Personnel Review, 35, 589-603.

Devine, D. J. (1999). Effects of cognitive ability, task knowledge, information sharing and conflict on group decision-making effectiveness. Small Group Research, 30, 608-634.

Dillen, R., \& Romme, G. (1997). Mapping the landscape of organizational learning. European Management Journal, 15(1), $68-78$.

Dixon, N. (2002). The neglected receiver of knowledge sharing. Ivey Business Journal, 66(4), 35-40.

Dobbins, G. H., \& Zaccaro, S. J. (1986). The effects of group cohesion and leader behavior on subordinate satisfaction. Group and Organization Studies, 11(3), 203-219.

Driver, M. (2003). Diversity and learning in groups. The Learning Organization, 10(2-3), 149-166.

Druskat, V. U., \& Kayes, D. C. (2000). Learning versus performance in short-term project teams. Small Group Research, 31, 328-353.

Edmondson, A. (1999). Psychological safety and learning behavior in work teams. Administrative Science Quarterly, 44, 350-383.

Edmondson, A., Bohmer, R., \& Pisano, G. (2001). Speeding up team learning. Harvard Business Review, 79, 125-132.

Ellis, A. P. J., Hollenbeck, J. R., Ilgen, D. R., Porter, C. O. L. H., West, B. J., \& Moon, H. (2003). Team learning: Collectively connecting the dots. Journal of Applied Psychology, 88, 821-835.

Hoopes, D. G., \& Postrel, S. (1999). Shared knowledge, "glitches", and product development performance. Strategic Management Journal, 20, 837-865.

Ickes, W., \& Gonzalez, R. (1994). "Social" cognition and social cognition. From the subjective to the intersubjective. Small Group Research, 25, 294-315.

Janis, I. L. (1972). Victims of groupthink. Boston: Houghton Mifflin.

Janis, I. L. (1982). Groupthink (2nd ed.). Boston: Houghton-Mifflin.

Janis, I. L. (1985). International crisis management in the nuclear age. Applied Social Psychology Annual, 6, 63-86.

Jarvis, P. (1995). Adult and continuing education. Theory and practice. London: Routledge.

Jehn, K. A. (1994). Enhancing effectiveness: An investigation of advantages and disadvantages of value-based intragroup conflict. International Journal of Conflict Management, 5, 223-238.

Jehn, K. A. (1995). A multimethod examination of the benefits and detriments of intragroup conflict. Administrative Science Quarterly, 40, 256-282.

Jehn, K. A., \& Mannix, E. A. (2001). The dynamic nature of conflict: A longitudinal study of intragroup conflict and group performance. The Academy of Management Journal, 44, 238-251.

Jonker, M. (2003). Solidarity behaviours: A research on reciprocity within the army. Unpublished Master's Thesis, Tilburg University, The Netherlands.

Kasl, E., Marsick, V. J., \& Dechant, K. (1997). Teams as learners: A research-based model of team learning. The Journal of Applied Behavioral Science, 33, 227-246.

Katzenbach, J., \& Smith, D. (1993). The wisdom of teams. Boston: Harvard Business School Press. 
Kidwell, J. R. E., Mossholder, K. W., \& Bennett, N. (1997). Cohesiveness and organizational citizenship behavior: A multilevel analysis using work groups and individuals. Journal of Management, 23, 775-793.

Klein, K. J., \& Kozlowski, S. W. J. (Eds.). (2000). Multilevel theory, research, and methods in organizations: Foundations, extensions, and new directions. San Francisco: Jossey-Bass.

Kluger, A. N., \& DeNisi, A. (1996). The effects of feedback interventions on performance: A historical review, a metaanalysis, and a preliminary feedback intervention theory. Psychological Bulletin, 119, 254-284.

Kofman, F., \& Senge, P. M. (1993). Communities of commitment: The heart of learning organizations. Organizational Dynamics, $22,5-23$.

Lambert, R., \& Peppard, J. (1993). Information technology and new organisational forms: Destination but no road map? Journal of Strategic Information Systems, 2(3), 180-205.

Lambooij, M., Sanders, K., Koster, F., et al. (2002). Basisvragenlijst onderzoeksprogramma solidarity at work [Questionnaire solidarity at work]. University of Groningen, The Netherlands.

Levitt, B., \& March, J. G. (1988). Organizational learning. Annual Review of Sociology, 14, 319-340.

MacKenzie, S., Podsakoff, P., \& Fetter, R. (1991). Organizational citizenship behavior and objective productivity as determinants of managerial evaluations of salespersons' performance. Organizational Behavior and Human Decision Processes, 50, $123-150$.

Maurer, T. J., Weiss, E. M., \& Barbeite, F. G. (2003). A model of involvement in work-related learning and development activity: The effects of individual, situational, motivational and age variables. Journal of Applied Psychology, 88, 707-724.

McDermott, R. (1999). Learning across teams: How to build communities of practice in team organizations. Knowledge Management Journal, 8(May/June), 32-36.

McEvily, S. K., \& Chakravarthy, B. (2002). The persistence of knowledge-based advantage: An empirical test for product performance and technological knowledge. Strategic Management Journal, 23, 285-305.

Michailova, S., \& Hutchings, K. (2006). National cultural influences on knowledge sharing: A comparison of China and Russia. Journal of Management Studies, 43, 383-405.

Mohammed, S., \& Angell, L. C. (2004). Surface- and deep-level diversity in workgroups; examining the moderating effects of team orientation and team process on relationship conflict. Journal of Organizational Behavior, 25, 1015-1039.

Moye, N. A., \& Langfred, C. W. (2004). Information sharing and group conflict: Going beyond decision making to understand the effects of information sharing on group performance. The International Journal of Conflict Management, 15, 381-410.

Mullen, B., \& Copper, C. (1994). The relation between group cohesiveness and performance: An integration. Psychological Bulletin, 115, 210-227.

Nonaka, I. (1994). A dynamic theory of organizational knowledge creation'. Organization Science, 5, 14-37.

Nonaka, I., \& Takeuchi, H. (1995). The knowledge creating company. How Japanese companies create the dynamics of innovation. New York: Oxford University Press.

Organ, D. W., Podsakoff, P. M., \& MacKenzie, S. B. (2006). Organizational citizenship behavior: Its nature, antecedents and consequences.. Thousand Oaks: Sage.

Pearsall, M. J., \& Ellis, A. P. J. (2006). The effects of critical team member assertiveness on team performance and satisfaction. Journal of Management, 32, 575-594.

Podolny, J. M., \& Baron, J. N. (1997). Relationships and resources: Social networks and mobility in the workplace. American Sociological Review, 62, 673-693.
Rastogi, P. N. (2000). Knowledge management and intellectual capital-the new virtuous reality of competitiveness. Human Systems Management, 19, 39-48.

Raudenbush, S. W., \& Bryk, A. S. (2002). Hierarchical linear models: Applications and data analysis methods (2nd ed.). Newbury Park, CA: Sage.

Sanders, K. (2004). Playing truant within organisations. Informal relationships, work ethics and absenteeism. Journal of Managerial Psychology, 19, 136-155.

Sanders, K., \& Hoekstra, S. K. (1998). Informal networks and absenteeism within an organization. Computational and Mathematical Organization Theory, 4, 149-163.

Sanders, K., \& Van Emmerik, H. (2004). Does modern organizations and governance threat solidarity? Journal of Management and Governance, 8, 351-372.

Sauquet, A. (2002). Conflict, team learning and sensemaking. Paper presented at the Euram 2002 Conference, Stockholm.

Schachter, S., Ellertson, S. J., McBride, D., \& Gregory, D. (1951). An experimental study of cohesiveness and productivity. Human Relations, 4, 229-238.

Senge, P. M. (1990). The fifth discipline: The art and practice of the learning organization. London: Doubleday.

Shaw, M. E. (1981). Group-dynamics: Psychology of small groups (8th ed.). New York: McGraw-Hill.

Shaw, J. B., \& Barrett-Power, E. (1998). The effects of diversity on small work group processes and performance. Human Relations, $51,1307-1325$.

Steiner, I. D. (1972). Group process and productivity. New York: Academic Press.

Stewart, G. L., \& Barrick, M. R. (2000). Team structure and performance: Assessing the mediating role of intra team process and the moderating role of task type. Academy of Management Journal, 43, 135-148.

Stock, R. (2004). Drivers of team performance: What do we know and what have we still to learn? Schmalenbach Business Review, 56(3), 274-306.

Swieringa, J., \& Wierdsma, A. F. M. (1990). Op weg naar een lerende organisatie [Heading for a learning organization]. Groningen: Wolters-Noordhof.

Tannenbaum, S. I. (1997). Enhancing continuous learning: Diagnostic findings from multiple companies. Human Resource Management, 36, 437-452.

Tindale, R. S., Kulik, C. T., \& Scott, L. A. (1991). Individual and group feedback and performance: An attributional perspective. Basic and Applied Social Psychology, 12, 41-62.

Tjepkema, S. (2003). The learning infrastructure of self-managing work teams. Dissertation, Enschede: Twente University Press.

Tjosvold, D., \& Yu, Z. (2004). Goal interdependence and applying abilities for team in-role and extra-role performance in china. Group Dynamics, 8, 98-111.

Turner, M. E., \& Pratkanis, A. R. (1997). Mitigating groupthink by stimulating constructive conflict. In C. K. W. D. Dreu \& E. van de Vliert (Eds.), Using conflict in organizations. London: Sage.

Van der Vegt, G., Emans, B., \& Van der Vliert, E. (1998). Motivating effects of task and outcome interdependence in work teams. Group \& Organization Management, 23(2), 124-143.

Van Offenbeek, M. (2001). Processes and outcomes of teamlearning. European Journal of Work and Organizational Psychology, 10, 303-317.

Wall, J. A. J., \& Callister, R. R. (1995). Conflict and its management. Journal of Management, 21, 515-558.

Wilke, H. A. M., \& Meertens, R. W. (1994). Group performance. London: Routledge.

Wilson, J. M., Goodman, P. S., \& Cronin, M. A. (2007). Group learning. Academy of Management Review, 32, 1041-1059. 